'Subdepartamento de Medicina, Hospital Base de Valdivia Valdivia, Chile. ${ }^{2}$ Instituto de Medicina, Facultad de Medicina, Campus Isla Teja, Universidad Austral de Chile. Valdivia, Chile

${ }^{3}$ Servicio de Farmacia, Hospital Base de Valdivia. Valdivia, Chile. ${ }^{4}$ Instituto de Farmacia, Facultad de Ciencias, Campus Isla Teja, Universidad Austral de Chile. Valdivia, Chile.

${ }^{5}$ Servicio de Ginecología y Obstetricia, Hospital Base de Valdivia. Valdivia, Chile. auímico Farmacéutico.

bInterna. Carrera de Medicina, Universidad Austral de Chile. Valdivia, Chile.

Conflicto de Interés: ninguno. Financiamiento: ninguno.

Recibido el 6 de octubre de 2019, aceptado el 18 de marzo de 2020 .

Correspondencia a: Dr. Alberto Fica Subdepartamento de Medicina, Hospital Base de Valdivia. Bueras 1003. Valdivia, Chile. albertoficacubillos@gmail.com

\section{Penicillin desensitization in allergic pregnant women with syphilis. Report of two cases}

\author{
ALBERTO FICA ${ }^{1,2}$, DANIEL MUÑOZ ${ }^{3,4, a}$, TAMARA ROJAS ${ }^{5}$, \\ CATALINA SANZANA ${ }^{\mathrm{b}}, \mathrm{CAMILA} \mathrm{MUNOOZ}^{\mathrm{b}}$
}

\begin{abstract}
Syphilis during pregnancy has a high risk of congenital transmission with disastrous fetal consequences. Penicillin (PNC) is the only effective antimicrobial for the treatment of pregnant women with syphilis. Chilean guidelines do not consider desensitization to PNC in these women. We report two cases of pregnant women aged 32 and 23 years, with immediate allergy to PNC and syphilis who were safely and successfully desensitized using a four-hour intravenous protocol in the critical care unit and who subsequently received benzathine G PNC. An electronic survey was conducted among approximately 100 Clinical Pharmacists $(C P)$ in the country. Of these, 16 answered and 13 reported having experience in drug desensitization, in at least five cases with PNC and none reported deaths or cardiorespiratory arrest. Desensitization to PNC can be carried out safely and in Chile, this alternative should be incorporated to the management of pregnant women with syphilis and immediate allergy to PNC, instead of using erythromycin.

(Rev Med Chile 2020; 148: 344-348)
\end{abstract}

Key words: Desensitization, Immunologic; Hipersensitivity; Penicillins; Pregnant Women; Syphilis.

\section{Desensibilización a penicilina en mujeres embarazadas alérgicas. Informe de dos casos}

La sifilis durante el embarazo tiene un alto riesgo de transmisión congénita con consecuencias desastrosas para el feto. La penicilina (PNC) es el único compuesto efectivo para el tratamiento de sifilis en una mujer embarazada.. En Chile, ante alergias de tipo inmediata, no se considera la desensibilización a la PNC en mujeres embarazadas por norma ministerial. Se comunican dos casos de mujeres embarazadas con alergia tipo inmediata y sifilis durante la gestación que fueron desensibilizadas a este compuesto con un protocolo endovenoso de 4 horas en la unidad de pacientes críticos, sin observar complicaciones, recibiendo posteriormente PNC G Benzatina. Se efectuó una encuesta electrónica a farmacéuticos clínicos del país que incluyó más de 100 profesionales. De ellos, 16 contestaron y 13 declararon poseer experiencia en desensibilización de fármacos, en al menos cinco casos con PNC y ninguno reportó muertes o paro cardiorrespiratorio. La desensibilización a PNC puede ser efectuada en forma segura en embarazadas con alergia de tipo inmediata a PNC que cursan con sifilis. En Chile se debería incorporar esta alternativa en el manejo de mujeres embarazadas con sifilis y alergia inmediata a PNC en lugar de solo considerar por norma el uso de eritromicina.

Palabras clave: Desensibilización Inmunológica; Hipersensibilidad a las Drogas; Mujeres Embarazadas; Penicilinas; Sifilis. 
S yphilis during pregnancy has a high risk of congenital transmission, especially during early stages of infection. Consequences include abortion, premature delivery, intrauterine growth retardation, perinatal death and congenital syphilis $^{1,2}$. Penicillin (PNC) is the only effective compound for the treatment of a pregnant mother with syphilis without resistant isolates identified so far and with rare therapeutic failures ${ }^{3}$. In case of penicillin allergy, options for the treatment of a pregnant woman with syphilis are contraindicated as tetracyclines or fail to prevent congenital infection such as macrolides ${ }^{4-8}$. Due to the unequivocal efficacy of penicillin in the treatment of pregnant women with syphilis and the absence of alternatives, guidelines of USA, Europe, United Kingdom, Spain, Canada, Australia and other countries recommend that in cases of allergy a desensitization to this compound should be carried out whenever possible $e^{9-11}$. In contrast to these recommendations, regulations in Chile do not consider desensitization as an option, and impose the use of erythromycin, a compound of recognized failure ${ }^{12}$. Because this option was published as a rule and not as a recommendation, it leaves no room to apply desensitization protocols ${ }^{13}$. The recent report of a serious case of congenital syphilis after macrolides use in a pregnant woman with syphilis in Chile, demonstrates the risk of these regulations and the imperative need to incorporate desensitization as a therapeutic option ${ }^{14}$.

PNC desensitization is a safe procedure when applied in a regulated and observed protocol ${ }^{15-18}$. Unfortunately, PNC desensitization appears to be mostly restricted to developed countries with only one small series reported in Brazil in Latin America ${ }^{15}$. This creates an inequity in the management of pregnant women with syphilis and immediate allergy to this compound in developing countries. Recently, we applied desensitization protocols in two pregnant women with syphilis and immediate type allergy to PNC that we would like to communicate. Details of the protocol used are given and its biological bases are discussed. The communication is complemented by a survey to Clinical Pharmacists about their experience in desensitization protocols. Patients gave their informed consent.

Case 1. In June 2019, a 32-year-old female pregnant patient (10 weeks) was admitted by a weak reactive VDRL (+) test and a reactive MHATP test. She had a history of a 1: 2 reactive VDRL test 18 months before without having received treatment. The patient did not have skin or mucous membranes lesions so the case was classified as latent syphilis. Two months earlier she received oral cloxacillin due to paronychia in a toe presenting a skin reaction with generalized pruritus associated with erythema and facial edema that occurred after half an hour of the first dose and lasted several hours. The treatment was discontinued. The reaction suggested an immediate type allergy and a PNC desensitization protocol was indicated. She was transferred to the Critical Care Unit (CCU) for monitoring and treatment of potential complications. Increasing doses of intravenous sodium PNC G were applied (Figure 1 , Table 1$)^{18}$. During the protocol, she remained asymptomatic and hemodynamically stable. The protocol was finalized in 4 hours and the first dose of benzathine penicillin $\mathrm{G}$ was administered (2.4 million units). She was observed for 48 hours and discharged. The patient received her second and third dose of benzathine PNC G in the following weeks, which were administered during brief hospitalizations of 48 hours for safety, without complications. Due to the long half-life of the compound, new desensitization protocols were not applied. Patient's partner was treated concomitantly. The study of the patient did not reveal HIV or hepatitis B virus coinfection.

Case 2. 23-year-old woman, multiparous of 1, with a 22-week pregnancy and secondary syphilis (condyloma lata and a VDRL 1:16 test) shortly before conception. She had a past history of amoxicillin allergy at 8 years of age with angioedema, erythema and respiratory compromise within few minutes of the first dose (immediate type). Due to her allergy, she received tetracycline for 15 days with accidental exposure of the embryo during the first days of pregnancy. Her partner was treated with benzathine PNC G. Despite the reduction of VDRL titers in subsequent months (weak reactive VDRL at 3 months of pregnancy and then undiluted reactive at the 4 th month), it was decided to apply a PNC desensitization protocol due to the possibility of a suboptimal treatment of maternal syphilis with tetracycline. She was transferred to the CCU and received the same protocol as the previous case, without complications. After that, 


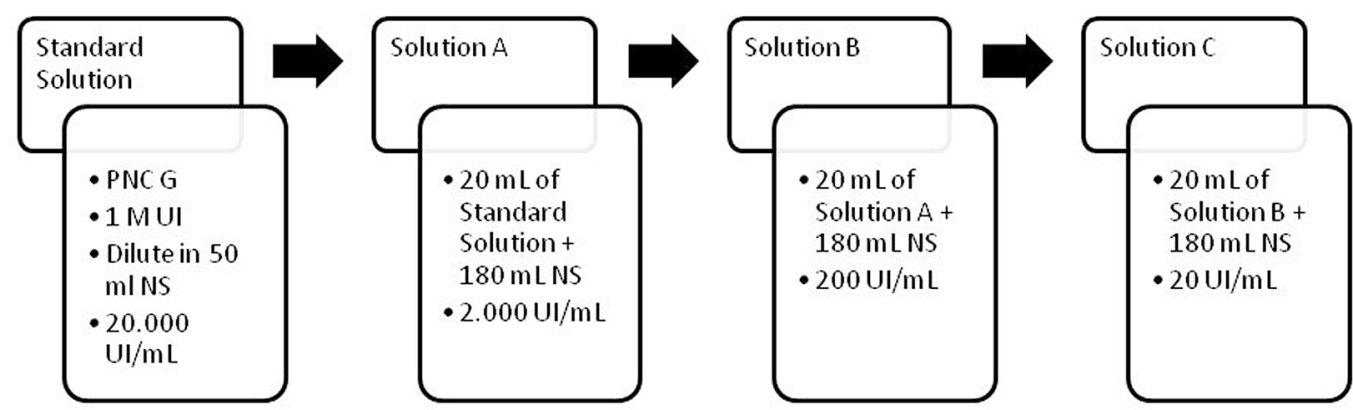

Figure 1. Diagram indicates how the different working solutions can be prepared from a standard solution. Initial infusion begins with solution C. NS: Normal Saline

Table 1. Intravenous PNC desensitization protocol and follow up of clinical parameters in a pregnant woman with syphilis

\begin{tabular}{|cccccccc|}
\hline Stage & Solution & $\begin{array}{c}\text { Infusion } \\
\text { rate }\end{array}$ & $\begin{array}{c}\text { Accumulated } \\
\text { PNC units }\end{array}$ & $\begin{array}{c}\text { Blood pressure } \\
\mathbf{m m} / \mathbf{H g}\end{array}$ & $\begin{array}{c}\text { Pulse rate/ } \\
\text { min }\end{array}$ & $\begin{array}{c}\text { Respiratory } \\
\text { rate /min }\end{array}$ & $\begin{array}{c}\text { Pulse } \\
\text { oximetry }\end{array}$ \\
\hline Basal & & & & $120 / 76$ & 70 & 16 & $96 \%$ \\
\hline 1 & Sol C & $10 \mathrm{ml} / \mathrm{h}$ & $50 \mathrm{U}$ & $120 / 71$ & 70 & 17 & $97 \%$ \\
\hline 2 & Sol C & $20 \mathrm{ml} / \mathrm{h}$ & $100 \mathrm{U}$ & $127 / 79$ & 72 & 16 & $96 \%$ \\
\hline 3 & Sol C & $40 \mathrm{ml} / \mathrm{h}$ & $200 \mathrm{U}$ & $120 / 73$ & 75 & 17 & $97 \%$ \\
\hline 4 & Sol C & $80 \mathrm{ml} / \mathrm{h}$ & $400 \mathrm{U}$ & $118 / 69$ & 73 & 19 & $97 \%$ \\
\hline 5 & Sol C & $160 \mathrm{ml} / \mathrm{h}$ & $800 \mathrm{U}$ & $119 / 67$ & 72 & 17 & $96 \%$ \\
\hline 6 & Sol B & $30 \mathrm{ml} / \mathrm{h}$ & $1.500 \mathrm{U}$ & $114 / 73$ & 80 & 16 & $97 \%$ \\
\hline 7 & Sol B & $60 \mathrm{ml} / \mathrm{h}$ & $3.000 \mathrm{U}$ & $120 / 69$ & 75 & 16 & $96 \%$ \\
\hline 8 & Sol B & $120 \mathrm{ml} / \mathrm{h}$ & $6.000 \mathrm{U}$ & $114 / 69$ & 69 & 15 & $96 \%$ \\
\hline 9 & Sol B & $240 \mathrm{ml} / \mathrm{h}$ & $12.000 \mathrm{U}$ & $109 / 68$ & 67 & 16 & $96 \%$ \\
\hline 10 & Sol A & $50 \mathrm{ml} / \mathrm{h}$ & $25.000 \mathrm{U}$ & $113 / 64$ & 67 & 17 & $97 \%$ \\
\hline 11 & Sol A & $100 \mathrm{ml} / \mathrm{h}$ & $50.000 \mathrm{U}$ & $115 / 75$ & 71 & 15 & $95 \%$ \\
\hline 12 & Sol A & $200 \mathrm{ml} / \mathrm{h}$ & $100.000 \mathrm{U}$ & $113 / 79$ & 90 & 13 & $95 \%$ \\
\hline 13 & Standard Solution & $40 \mathrm{ml} / \mathrm{h}$ & $200.000 \mathrm{U}$ & $115 / 76$ & 75 & 14 & $97 \%$ \\
\hline 14 & Standard Solution & $80 \mathrm{ml} / \mathrm{h}$ & $400.000 \mathrm{U}$ & $112 / 74$ & 77 & 16 & $97 \%$ \\
\hline End & & & & & 77 & 14 & $99 \%$ \\
\hline
\end{tabular}

Procedure (adapted from reference 18): Drug solution C drug is administered for 15 minutes at the indicated infusion rate. After completing 15 minutes, the next dose is continued, in this case twice the previous infusion rate. Next doses are continued every 15 minutes. Observe carefully when the next dose jumps to a new solution (B, A or Standard). Observe appearance of rash, bronchoconstriction, bradycardia, hypotension or arrhythmia on the monitor. If a flow meter is available, maximum expiratory flow can be measured. In case of adverse reaction, immediately stop the infusion, administer chlorphenamine 10 mg IV and reevaluate. If necessary, apply hydrocortisone $100 \mathrm{mg} \mathrm{IV} \mathrm{or} \mathrm{epinephrine.} \mathrm{Once} \mathrm{the} \mathrm{event} \mathrm{is} \mathrm{resolved,} \mathrm{restart} \mathrm{with}$ the previous tolerated dose. 
she received the first dose of benzathine G PNC. An obstetric ultrasound was performed showing a single live fetus in a cephalic presentation, with normal amniotic fluid, morphology, and estimated weight of $497 \mathrm{~g}$. After being discharged, she was shortly admitted in the next week to receive the second dose of benzathine PNC G without complications. HIV and hepatitis B serology was negative.

\section{Questionnaire about PNC desensitization protocols by Clinical Pharmacists in Chile}

During June 2019, an electronic questionnaire was sent to a network of CP in Chile that include near 140 members. Sixteen of them answered the poll including 7 that work in the Metropolitan Region, 6 in the Southern Chile and 3 that not indicated their workplace. Thirteen declared to have experience in drug desensitization protocols (range 1 to $>10$ times). Desensitization to sulfonamides (12 events), penicillins (5 events), cephalosporins and carbapenems (3 each one) were declared. The group also declared isolated experiences with vancomycin (twice), NSAIDS, cancer drugs and amphotericin B (one in every case). None of the $\mathrm{CP}$ that answered the poll indicated death or anaphylactic shock during protocol application. Transitory rash and fever were commented by 5 and 3 professionals, respectively.

\section{Discussion}

Cases and background presented in this paper demonstrate that PNC desensitization in pregnant women with syphilis and beta-lactams immediate type allergy is a safe and fast procedure, which can be carried out in public hospitals, and has a protocol and trained professionals available to perform it. Despite being a safe therapeutic strategy reported several decades ago in developed countries, the experience published in Latin America is scarce and restricted to Brazil ${ }^{15}$. Absence of related literature in developing countries limits its application and creates inequities during women healthcare. This bias is amplified in Chile by a rule that does not consider PNC desensitization for immediate type allergic among pregnant women with syphilis in clear contrast with policies in developed regions and countries ${ }^{10-12}$. Our group recently reported the serious consequences of the use of macrolides in the management of a pregnant woman with syphilis and the need for PNC desensitization protocols $^{14}$. This type of protocols is even more necessary considering the current epidemiological situation with an increase of syphilis rates in the Chilean population. It can also be applied in allergic patients with enterococcal endocarditis.

A desensitization protocol allows a temporary tolerance to the compound involved but not to cure the allergy. Progressive exposure to increasing concentrations of the compound avoids activation of intracellular cascade that allows mast cell degranulation. The release of histamine mediators, tumor necrosis factor, lipid mediators (leukotrienes), cytokines and intracellular calcium influx is blocked ${ }^{17,19,20}$.

We choose to apply these protocols in the CCU for safety but the place of application can be simplified according to the experience of the group, maintaining close monitoring and resources for the management of an eventual anaphylaxis. In any case, they were executed in few hours facilitating the release of CCU beds.

Desensitization to PNC is not advised in patients with asthma, in those with poor cardiovascular reserve and in patients unable to suspend beta-blockers. It is also contraindicated in patients with vasculitis or vesicular skin lesions, Stevens-Johnson syndrome or DRESS ${ }^{17,19,20}$. For mild non-immediate type allergies, ceftriaxone can be used, which in a meta-analysis has been shown to be therapeutically equivalent to penicillin in adult patients with syphilis ${ }^{21}$.

This work has limitations that must be considered. Only two cases without complications were included. Addition of more patients could demonstrate mild or moderate complications such as rash and urticaria. However, it is difficult to include more cases due to the current regulatory restriction in Chile that establishes the mandatory use of macrolides in these cases. Allergy was not confirmed by skin tests because they were not available at the local hospital and several substances must be included. However, the temporal relationship, rapid appearance of symptoms and type of symptoms detected strongly suggest an immediate type allergy. Ideally, a previous study should be available but if not, desensitization does not cause harm in a patient 
without hypersensitivity but opens the door to a treatment that would otherwise be forbidden. Finally, the poll was answered by few $\mathrm{CP}$ allowing only a preliminary impression. Clinical immunologists have also great experience in these protocols but unfortunately are not always available in regional hospitals.

In conclusion, PNC desensitization can be carried out safely in pregnant women with syphilis and immediate allergy to PNC with a rapid application protocol. The health system in Chile should incorporate this alternative in the management of pregnant mothers with syphilis instead of just considering the use of erythromycin as a rule. $\mathrm{CP}$ have experience in these protocols.

Acknowledgments: To Dr. Carolina Díaz Gallardo, Clinical immunologist for her critical review of the manuscript.

\section{References}

1. Cooper JM, Sánchez PJ. Congenital syphilis. Semin Perinatol 2018; 42 (3): 176-84.

2. Rac MWF, Revell PA, Eppes CS. Syphilis during pregnancy: A preventable threat to maternal-fetal health. Am J Obstet Gynecol 2017; 216 (4): 352-63.

3. Conover CS, Rend CA, Miller GB Jr, Schmid GP. Congenital syphilis after treatment of maternal syphilis with a penicillin regimen exceeding CDC guidelines. Infect Dis Obstet Gynecol 1998; 6 (3): 134-7.

4. Holder WR, Knox JM. Syphilis in pregnancy. Med Clin North Am 1972; 56 (5): 1151-605.

5. Fenton LJ, Light IJ. Congenital syphilis after maternal treatment with erythromycin. Obstet Gynecol 1976; 47 (4): 492-4.

6. Zhou P, Qian Y, Xu J, Gu Z, Liao K. Occurrence of Congenital Syphilis After Maternal Treatment with Azithromycin During Pregnancy. Sex Trans Dis 2007; 34 (7): 472-4.

7. Eltabbakh GH, Elejalde BR, Broekhuizen FF. Primary syphilis and nonimmune fetal hydrops in a penicillin-allergic woman. A case report. J Reprod Med 1994; 39 (5): 412-4.

8. Ricci JM, Fojaco RM, O’Sullivan MJ. Congenital syphilis: The University of Miami/Jackson Memorial Medical Center experience, 1986-1988. Obstet Gynecol 1989; 74 (5): 687-93.

9. Hashisaki P, Wertzberger GG, Conrad GL, Nichols CR. Erythromycin failure in the treatment of syphilis in a pregnant woman. Sex Transm Dis 1983; 10 (1): 36-8.

10. Workowski KA, Bolan GA. Sexually transmitted disease treatment guidelines, 2015. MMWR Recomm Rep. 2015; 64 (RR-03): 1-137.

11. Janier M, Hegyi V, Dupin N, Unemo M, Tiplica GS, Potočnik M, et al. 2014 European guideline for the management of syphilis. J Eur Acad Dermatol Venereol 2014; 28 (12): 1581-93.

12. Kingston M, French P, Higgins S, McQuillan O, Sukthankar A, Stott C, et al. UK national guidelines on the management of syphilis 2015. Int J STD AIDS 2016; 27 (6): 421-46.

13. Ministerio de Salud, Chile. Norma de profilaxis, diagnóstico y tratamiento de las infecciones de transmisión sexual (ITS). 2016. available at: https://www.cemera. $\mathrm{cl} /$ sogia/pdf/2016/Norma\%20de\%20Profilaxis $\% 20$ Diagnoostico\%20y\%20Tratamiento\%20de\%20las\%20 Infecciones\%20de\%20Transmision\%20Sexual.pdf. Visited september 2019.

14. Fica A, Täger M, Muñoz D, Guerra F, Vargas J. Congenital syphilis after maternal macrolide therapy in a presumed penicillin allergic patient. Time to change the Chilean governmental normative. Rev Med Chile 2019; 147: 944-46.

15. Dallé J, Ramos MC, Jimenez MF, Escobar FG, Antonello VS. Oral desensitization to penicillin for the treatment of pregnat women with syphilis: A successful program. Rev Bras Ginecol Obstet 2018; 40(1):43-46.

16. Wendel GD Jr, Stark BJ, Jamison RB, Molina RD, Sullivan TJ. Penicillin allergy and desensitization in serious infectious during pregnancy. N Engl J Med 1985; 312 (19): 1229-32.

17. Pham MN, Ho HE, Desai M. Penicillin desensitization: Treatment of syphilis in pregnancy in penicillin-allergic patients. Ann Allergy Asthma Immunol 2017; 118 (5): 537-41.

18. Chastain DB, Hutzley VJ, Parekh J, Alegro JV. Antimicrobial desensitization: A review of published protocols. Pharmacy (Basel) 2019; 7 (3). Pii: E112 .

19. de las Vecillas Sánchez L, Alenazy LA, García-Neuer M, Castells MC. Drug hypersensitivity and desensitizations: Mechanisms and new approaches. Int J Mol Sci 2017; 18: 1316 .

20. Cernadas JR, Brockow K, Romano A, Aberer W, Torres MJ, Bircher A, et al. General considerations on rapid desensitization for drug hypersensitivity - a consensus statement. Allergy 2010; 65: 1357-66.

21. Liang Z, Chen YP, Yang CS, Guo W, Jiang XX, Xu XF, et al. Meta-analysis of ceftriaxone compared with penicillin for the treatment of syphilis. Int J Antimicrob Agents 2016; 47 (1): 6-11. 